\title{
The influence of habitat and seed mixture on the botanical composition of dykes in the North-East Polder
}

\author{
A. C. BOER, A. J. CAVE and J. J. JONKER \\ IJsselmeer Polders Development Authority, Kampen, Netherlands
}

\section{Summary}

In 1949 and 1954 various grass-seed mixtures were sown on the dyke of the North-East Polder in an attempt to find a mixture that would forme a dense grass sward.

The relation between habitat and area covered with the species is given in TABLE 2 for the older experimental fields at Lemmer and Schokkerhaven, and in TABLE 4 for the more recent experimental field at Rotterdamse Hoek.

The differences may be due to differences in moisture supply. Some indications of the specific interaction were found on the experimental field at Rotterdamse Hoek. When Festuca rubra was included in the seed mixture, Lolium perenne and Agrostis stolonifera were less frequent on the plots. To a lesser extent the same is true of the interaction between Agrostis stolonifera and Lolium perenne and Festuca rubra.

These experiments did not solve the original problem.

\section{Introduction}

Dykes are protected from the surge and flow of water by stones or other durable material. The erosive effect of rain and wind is checked by a grass cover.

The grassswards of new dykes, e.g. those of the reclaimed IJsselmeer polders, is obtained by sowing. The species used for this purpose must be solid mat-formers. A mixture of species is preferably used to decrease the risk of failure when using a monospecific sward.

The development of the grass sward of dykes is mainly influenced by the moisture supply, rooting depth, temperature and use. As regards moisture supply, the plants depend on the water provided by the soil and precipitation. The temperature is influenced by the orientation and gradient of the dykes. The rooting depth depends on the nature and thickness of the soil layer covering the sand or boulder-clay centre of the dyke. The type of use is also determined by the angle of inclination.

An investigation of the most suitable grass-seed mixture for dykes entails the following problems: -

a. the influence of the said habitat factors on the ultimate botanical composition;

b. the influence of the mixture on the botanical composition.

\section{Experimental design}

In 1949 experiments with grass-seed mixtures were started at two sites on the dyke near Lemmer and Schokkerhaven. The habitat factors were: -

Received for publication 8th January, 1965. 
1. north and south orientation respectively;

2. gradient of $1: 2.5$ and $1: 3$;

3. $40 \mathrm{~cm}$ and $70 \mathrm{~cm}$ layers of silt loam at Schokkerhaven and silty clay loam at Lemmer.

The composition of the seed mixtures was as follows (in $\mathrm{kg} / \mathrm{ha}$ ): -

\begin{tabular}{rrrrr}
\multicolumn{7}{c}{ Mixture } \\
\hline $\mathrm{a}$ & $\mathrm{b}$ & $\mathrm{c}$ & $\mathrm{d}$ & $\mathrm{e}$ \\
& 10 & & 15 & \\
& 10 & 15 & & \\
4 & & & & \\
4 & & & & \\
18 & 6 & 6 & 6 & 15 \\
6 & 10 & 15 & 15 & 10 \\
6 & 6 & 6 & 6 & 6 \\
\hline 38 & 42 & 42 & 42 & 31
\end{tabular}

Agrostis stolonifera

Festuca rubra

Festuca pratensis

Phleum pratense

Lolium perenne

Poa pratensis

Trifolium repens

$\ldots \ldots \ldots \ldots$

Each mixture was sown in duplicate on plots of $5 \times 5 \mathrm{~m}$.

In 1954 a third experiment was started near Rotterdamse Hoek, with the following habitat factors: -

1. south-east orientation;

2. gradient $1: 2.5$ (A), $1: \infty$ (B), $1: 2.5$ (C), $1: 5$ (D) and $1: 30$ (E) in sequence from the top to the bottom of the dyke;

3. the soil on plots $A, B$ and $C$ is a silty clay loam, whereas that on $D$ and $E$ is sand.

The composition of the seed mixtures was as follows (in $\mathrm{kg} / \mathrm{ha}$ ): -

Agrostis stolonifera . . . . . . .

Festuca rubra

Poa pratensis

Mixture

Festuca pratensis

Lolium perenne ......... 15

Trifolium repens

\begin{tabular}{rrrrrrl}
\hline a & b & c & d & e & f & g \\
& & 15 & & 10 & 10 & 7.5 \\
& 15 & & 10 & & 10 & 7.5 \\
15 & & & 10 & 10 & & 7.5 \\
5 & 5 & 5 & 5 & 5 & 5 & 5 \\
15 & 15 & 15 & 15 & 15 & 15 & 15 \\
5 & 5 & 5 & 5 & 5 & 5 & 5 \\
\hline 40 & 40 & 40 & 45 & 45 & 45 & 47.5
\end{tabular}

These seed mixtures were also sown in duplicate on $10 \mathrm{~m}$ plots (dyke direction) and $9,6,3,12,14 \mathrm{~m}$ wide for habitats $\mathrm{A}, \mathrm{B}, \mathrm{C}, \mathrm{D}$ and 1 respectively.

All three experimental fields were sown after the original sward had been broken up. In 1950 the experimental fields at Lemmer and Schokkerhaven were placed at the disposal of farmers using the adjoining dyke sections. Grazing and management were good at Lemmer. At Schokkerhaven grazing was less intensive and mowing increased; during the last few years the plots were hayed only. The experimental field near Rotterdamse Hoek was alternately mown and grazed. Afterwards it was also placed at the disposal of the neighbouring farmers. Here the grazing and management were good. In all cases sheep were used for grazing.

The composition of the sward was determined in the early and late summer of 1961 , 1962, 1963 and 1964. The area covered by each species was estimated as percentages 
of the total surface. The estimates made in the early summer of 1964 were used in the statistical treatment. The Wilcoxon-T test (TATE and Clelland, 1959) was used for investigating the effect of the various habitat factors on the coverage of the species. The influence of the seed mixture on the botanical composition of the sward was determined by KENDALL's (1948) "coefficient of concordance W".

\section{Results}

In order to solve the above problems particular attention should be paid to the composition of the sward during the last year, as this situation is closest to the final situation. On the experimental fields at Lemmer and Schokkerhaven the plots showed no significant differences due to the composition of the original mixtures in 1964 . TABLE 1 therefore shows the averages of the five seed mixtures.

TABLE 1. Average area (\%) covered by the various species on the experimental fields near Lemmer and Schokkerhaven

\begin{tabular}{|c|c|c|c|c|c|c|c|c|c|}
\hline \multicolumn{2}{|c|}{ Locality } & \multirow{2}{*}{$\begin{array}{l}\text { Depth } \\
\text { soil layer }\end{array}$} & \multirow{2}{*}{$\begin{array}{l}\text { Orien- } \\
\text { tation }\end{array}$} & \multicolumn{6}{|c|}{ Area $(\%)$ covered by } \\
\hline & & & & As & $\mathrm{Fr}$ & $\mathbf{L p}$ & $\mathrm{Pp}$ & $\mathbf{P t}$ & Trif \\
\hline \multirow[t]{2}{*}{ Lemmer } & $\begin{array}{l}\text { land-side } \\
\text { lake-side }\end{array}$ & $\begin{array}{l}40 \\
40\end{array}$ & $\begin{array}{l}\mathbf{S} \\
\mathbf{N}\end{array}$ & $\begin{array}{r}2 \\
26\end{array}$ & $\begin{array}{l}54 \\
41\end{array}$ & $\begin{array}{l}0 \\
5\end{array}$ & $\begin{array}{l}2 \\
1\end{array}$ & $\begin{array}{l}0 \\
2\end{array}$ & $\begin{array}{l}0 \\
1\end{array}$ \\
\hline & $\begin{array}{l}\text { land-side } \\
\text { lake-side }\end{array}$ & $\begin{array}{l}70 \\
70\end{array}$ & $\begin{array}{l}\mathbf{S} \\
\mathbf{N}\end{array}$ & $\begin{array}{r}3 \\
20\end{array}$ & $\begin{array}{l}52 \\
42\end{array}$ & $\begin{array}{l}1 \\
7\end{array}$ & $\begin{array}{l}1 \\
1\end{array}$ & $\begin{array}{l}0 \\
2\end{array}$ & $\begin{array}{l}0 \\
0\end{array}$ \\
\hline \multirow[t]{2}{*}{ Schokkerhaven } & $\begin{array}{l}\text { lake-side } \\
\text { land-side }\end{array}$ & $\begin{array}{l}40 \\
40\end{array}$ & $\begin{array}{l}\mathbf{S} \\
\mathbf{N}\end{array}$ & $\begin{array}{l}1 \\
2\end{array}$ & $\begin{array}{l}44 \\
42\end{array}$ & $\begin{array}{l}4 \\
2\end{array}$ & $\begin{array}{l}2 \\
0\end{array}$ & $\begin{array}{l}0 \\
0\end{array}$ & $\begin{array}{l}1 \\
0\end{array}$ \\
\hline & $\begin{array}{l}\text { lake-side } \\
\text { land-side }\end{array}$ & $\begin{array}{l}70 \\
70\end{array}$ & $\stackrel{\mathbf{S}}{\mathbf{N}}$ & $\begin{array}{l}1 \\
2\end{array}$ & $\begin{array}{l}12 \\
39\end{array}$ & $\begin{array}{l}33 \\
13\end{array}$ & $\begin{array}{l}7 \\
0\end{array}$ & $\begin{array}{l}2 \\
1\end{array}$ & $\begin{array}{l}5 \\
2\end{array}$ \\
\hline $\begin{array}{l}\text { As }=\text { Agrosti } \\
\mathbf{F r}=\text { Festuca } \\
\mathbf{L p}=\text { Lolium } \\
\mathbf{P p}=\text { Poa pro } \\
\mathbf{P t}=\text { Poa tri }\end{array}$ & $\begin{array}{l}\text { stolonifera } \\
\text { rubra } \\
\text { perenne } \\
\text { tensis } \\
\text { ialis }\end{array}$ & $\begin{array}{l}\text { Fp } \\
\text { Br } \\
\text { Trif } \\
\text { Spec }\end{array}$ & div. & $\begin{array}{l}\text { Festu } \\
\text { Brom } \\
\text { Trifo } \\
\text { herbs }\end{array}$ & $\begin{array}{l}\text { prate } \\
\text { moll } \\
n \text { rep }\end{array}$ & & & & \\
\hline
\end{tabular}

Selective sheep grazing and the small size of the plots may have stimulated the unifying process in the composition of the sward. The sheep did not feed on Festuca rubra, so that this species was able to form seed. The influence of the adjoining plots was considerable owing to their small size.

It was observed that the sheep preferred the land-side of the dyke. This may explain the fact that there was a higher percentage of Lolium perenne on the lake-side than on the land-side.

In TABLE 2 the coverage of various species is compared with different habitat factors. When the species concerned show differences with a Wilcoxon- $T$ test improbability of less than $5 \%$ they are designated + and - in the table; + denotes that the species is more frequent in this condition than in its alternative. Insignificant differences are indicated by a dot.

Various conditions mentioned in TABLE 2 are important for the moisture supply. The Lolium perenne, Poa trivialis and Trifolium repens group usually responds differently from the Agrostis stolonifera and Festuca rubra group. The last two species are more highly drought-resistant than the first group (KRUIJNE, DE VRIES and Moor, 1963). DE VRIEs (1958) noted corresponding responses in his investigation of a large number of grass covers on river and sea dykes. 
TABLE 2. Relation between habitat factors and the area covered by some species on the experimental fields at Lemmer and Schokkerhaven according to the Wilcoxon-T test

\begin{tabular}{|c|c|c|c|c|c|c|}
\hline & As & Fr & $\mathrm{Lp}$ & $\mathrm{Pp}$ & $\mathbf{P t}$ & Trif \\
\hline$\ldots \ldots \ldots \ldots \ldots$ & + & - & - & 一 & + & - \\
\hline$\ldots \ldots \ldots$ & - & - & - & + & - & - \\
\hline $40 \mathrm{~cm}$ soil layer $\ldots \ldots \ldots \ldots$ & - & - & - & - & - & - \\
\hline $70 \mathrm{~cm}$ soil layer $\ldots \ldots \ldots$ & - & - & + & - & + & + \\
\hline Lake-side $\ldots \ldots \ldots \ldots$ & - & - & - & + & + & + \\
\hline Land-side $\ldots \ldots \ldots \ldots$ & - & + & - & - & - & - \\
\hline Lemmer . . . . . . . . . . & + & + & - & - & - & - \\
\hline Schokkerhaven $\ldots \ldots \ldots$ & - & - & + & - & - & + \\
\hline
\end{tabular}

$+=$ the species is significantly more frequent under these conditions.

$-=$ the species is significantly less frequent under these conditions.

- = no significant difference.

The botanical composition of the plots near Rotterdamse Hoek still showed some influence of the original (pre-1954) mixtures in 1964 (TABLE 3). As in the earlier experiments, the habitat exerts a great deal of influence.

The Wilcoxon-T test was also applied to this data, the results being shown in TABLE 4 . These results agree with those given in TABLE 2 and may also be due to differences in the moisture supply. For instance, unlike steeply inclined sandy soil (gradient $1: 5$ ), much more Lolium perenne, Poa trivialis, Trifolium repens and Festuca pratensis are found on flat sandy soil (gradient $1: 30$ ), Festuca rubra and Agrostis stolonifera being infrequent. On the silty clay loam the differences between a flat and sloping soil are only shown by a somewhat lower coverage of Lolium perenne and Trifolium repens.

The percentage coverage of Agrostis stolonifera (As), Festuca rubra (Fr) and Lolium perenne (Lp) partly depends on whether or not these species are included in the mixture and partly on the area covered by other species. This was found by ranking all plots of habitats $\mathrm{A}, \mathrm{B}, \mathrm{C}$ and $\mathrm{D}$ near Rotterdamse Hoek according to the percentage coverage of the three said species (TABLE 5). The agreement between the rankings of the mixtures a to g, estimated by KeNDALL's (1948) coefficient of concordance "W", appears to be high with an improbability of less than $1 \%$.

If mixture a in TABLE $5 \mathrm{~A}$ is ignored for the moment the effect of sowing Agrostis stolonifera is clear. The plots from which Agrostis stolonifera was omitted appear to the left of the plots in which this grass was sown.

The importance of sowing or not sowing Festuca rubra together with Agrostis stolonifera is reflected in the ranking, as can be seen in the sequence of the plots sown with mixtures $g, f, c$ and $e$.

The place of a between $g$ and $f$ is due to the extremely small differences in the coverage of Agrostis stolonifera on these plots. No further inferences can be drawn from this, as more Lolium perenne grew on the plots sown with mixture a than on any of the other plots.

TABLE 5 B shows that, as in the case of Agrostis stolonifera, plots sown with the mixtures containing Festuca rubra show a greater coverage of this species than the other plots.

Mixtures $g$ and $f$ show that the reduced coverage of Festuca rubra is due to the presence of Agrostis stolonifera in the seed mixture. These mixtures contained both Festuca rubra and Agrostis stolonifera. 
TABLE 3. Average area (\%) covered by the various species on the experimental field near Rotterdamse Hoek in 1964. The figures and symbols in bold print relate to the species sown in 1954

\begin{tabular}{|c|c|c|c|c|c|c|c|c|c|c|c|}
\hline \multirow{2}{*}{$\begin{array}{l}\text { Soil } \\
\text { type }\end{array}$} & \multirow[t]{2}{*}{ Gradient } & \multirow{2}{*}{$\begin{array}{l}\text { Mix- } \\
\text { ture }\end{array}$} & \multicolumn{9}{|c|}{ Area $(\%)$ covered by } \\
\hline & & & As & $F p$ & $\mathrm{Fr}$ & $L p$ & $\mathbf{P p}$ & $\mathrm{Br}$ & $\mathbf{P t}$ & Trif & $\begin{array}{l}\text { Spec } \\
\text { div. }\end{array}$ \\
\hline $\begin{array}{l}\text { Silty cl } \\
\text { loam }\end{array}$ & $\begin{array}{c}\mathbf{A} \\
1: 2.5\end{array}$ & $\begin{array}{l}\mathbf{a} \\
\mathbf{b} \\
\mathbf{c} \\
\mathbf{d} \\
\mathbf{e} \\
\mathbf{f} \\
\mathbf{g}\end{array}$ & $\begin{array}{c}2 \\
+ \\
2 \\
1 \\
\mathbf{3} \\
\mathbf{1} \\
\mathbf{1}\end{array}$ & $\begin{array}{l}+ \\
+ \\
\frac{+}{+} \\
+ \\
+\end{array}$ & $\begin{array}{l}24 \\
32 \\
26 \\
31 \\
31 \\
34 \\
29\end{array}$ & $\begin{array}{l}2 \\
1 \\
1 \\
1 \\
2 \\
1 \\
1\end{array}$ & $\begin{array}{c}1 \\
1 \\
1 \\
1 \\
1 \\
1 \\
+\end{array}$ & $\begin{array}{l}5 \\
1 \\
2 \\
1 \\
2 \\
1 \\
1\end{array}$ & $\begin{array}{l}+ \\
+ \\
+ \\
+ \\
+ \\
+ \\
+\end{array}$ & $\begin{array}{l}+ \\
+ \\
+ \\
+ \\
+ \\
+ \\
+\end{array}$ & $\begin{array}{l}1 \\
1 \\
1 \\
1 \\
1 \\
1 \\
1\end{array}$ \\
\hline & $1:{ }^{\mathbf{B}}$ & $\begin{array}{l}\text { a } \\
\mathrm{b} \\
\mathrm{c} \\
\mathrm{d} \\
\mathrm{e} \\
\mathrm{f} \\
\mathrm{g}\end{array}$ & $\begin{array}{r}2 \\
+ \\
7 \\
1 \\
15 \\
4 \\
4\end{array}$ & $\begin{array}{l}+ \\
+ \\
+ \\
+ \\
+ \\
+ \\
+\end{array}$ & $\begin{array}{l}22 \\
\mathbf{4 0} \\
25 \\
36 \\
22 \\
\mathbf{1 8} \\
\mathbf{3 0}\end{array}$ & $\begin{array}{r}15 \\
4 \\
8 \\
3 \\
6 \\
2 \\
2\end{array}$ & $\begin{array}{c}2 \\
1 \\
1 \\
+ \\
2 \\
+ \\
1\end{array}$ & $\begin{array}{r}6 \\
2 \\
4 \\
+ \\
3 \\
1 \\
+\end{array}$ & $\begin{array}{l}1 \\
+ \\
+ \\
+ \\
+ \\
+ \\
+\end{array}$ & $\begin{array}{r}2 \\
1 \\
2 \\
+ \\
1 \\
+ \\
+\end{array}$ & $\begin{array}{l}2 \\
1 \\
2 \\
1 \\
1 \\
1 \\
1\end{array}$ \\
\hline & $\begin{array}{c}\mathbf{C} \\
1: 2.5\end{array}$ & $\begin{array}{l}\text { a } \\
\text { b } \\
\mathbf{c} \\
\text { d } \\
\text { e } \\
\mathbf{f} \\
\mathbf{g}\end{array}$ & $\begin{array}{r}1 \\
+ \\
2 \\
1 \\
\mathbf{3} \\
\mathbf{1} \\
\mathbf{1}\end{array}$ & $\frac{+}{\frac{+}{+}}$ & $\begin{array}{l}\mathbf{3 1} \\
\mathbf{3 6} \\
\mathbf{3 1} \\
\mathbf{3 6} \\
\mathbf{3 2} \\
\mathbf{3 2} \\
\mathbf{3 4}\end{array}$ & $\begin{array}{r}3 \\
+ \\
2 \\
1 \\
2 \\
1 \\
+\end{array}$ & $\begin{array}{l}+ \\
+ \\
+ \\
+ \\
+ \\
+ \\
+\end{array}$ & $\begin{array}{c}2 \\
1 \\
2 \\
1 \\
1 \\
1 \\
+\end{array}$ & $\begin{array}{l}+ \\
+ \\
+ \\
+ \\
+ \\
+ \\
+\end{array}$ & $\begin{array}{l}+ \\
+ \\
+ \\
+ \\
+ \\
+ \\
+\end{array}$ & $\begin{array}{c}1 \\
1 \\
1 \\
+ \\
1 \\
1 \\
1\end{array}$ \\
\hline Sand & $\begin{array}{l}\mathrm{D} \\
1: 5\end{array}$ & $\begin{array}{l}\mathbf{a} \\
\mathbf{b} \\
\mathbf{c} \\
\mathbf{d} \\
\mathbf{e} \\
\mathbf{f} \\
\mathbf{g}\end{array}$ & $\begin{array}{r}4 \\
1 \\
16 \\
1 \\
12 \\
3 \\
3\end{array}$ & $\begin{array}{l}+ \\
+ \\
+ \\
+ \\
+ \\
+ \\
+\end{array}$ & $\begin{array}{l}\mathbf{3 3} \\
\mathbf{5 1} \\
36 \\
\mathbf{5 6} \\
\mathbf{3 7} \\
\mathbf{5 2} \\
\mathbf{5 5}\end{array}$ & $\begin{array}{r}15 \\
3 \\
4 \\
2 \\
3 \\
3 \\
3\end{array}$ & $\begin{array}{l}2 \\
1 \\
2 \\
1 \\
1 \\
1 \\
1\end{array}$ & $\begin{array}{l}1 \\
+ \\
+ \\
+ \\
+ \\
+ \\
+\end{array}$ & $\begin{array}{l}1 \\
+ \\
+ \\
+ \\
+ \\
+ \\
+\end{array}$ & $\begin{array}{c}6 \\
3 \\
1 \\
+ \\
+ \\
+ \\
1\end{array}$ & $\begin{array}{l}7 \\
5 \\
7 \\
3 \\
4 \\
5 \\
7\end{array}$ \\
\hline & $\begin{array}{c}\mathrm{E} \\
1: 30\end{array}$ & $\begin{array}{l}\mathrm{a} \\
\mathrm{b} \\
\mathrm{c} \\
\mathrm{d} \\
\mathrm{e} \\
\mathrm{f} \\
\mathrm{g}\end{array}$ & $\begin{array}{l}\overline{-} \\
\overline{-} \\
\overline{-} \\
\overline{-}\end{array}$ & $\begin{array}{l}4 \\
6 \\
6 \\
4 \\
6 \\
6 \\
7\end{array}$ & $\begin{array}{l}+ \\
+ \\
+ \\
+ \\
- \\
+\end{array}$ & $\begin{array}{l}\mathbf{3 7} \\
\mathbf{3 7} \\
\mathbf{3 0} \\
\mathbf{3 6} \\
\mathbf{3 2} \\
\mathbf{3 1} \\
\mathbf{2 9}\end{array}$ & $\begin{array}{l}1 \\
1 \\
2 \\
2 \\
3 \\
3 \\
2\end{array}$ & $\begin{array}{l}+ \\
+ \\
+ \\
+ \\
+ \\
+ \\
+\end{array}$ & $\begin{array}{l}20 \\
16 \\
17 \\
14 \\
15 \\
17 \\
15\end{array}$ & $\begin{array}{r}9 \\
10 \\
13 \\
12 \\
12 \\
9 \\
8\end{array}$ & $\begin{array}{l}4 \\
8 \\
8 \\
4 \\
7 \\
8 \\
8\end{array}$ \\
\hline
\end{tabular}

The fact that the effect of Agrostis stolonifera on the coverage of Festuca rubra is smaller than the effect of Festuca rubra on Agrostis stolonifera can be deduced from the ranking of the plots sown with mixtures $\mathrm{c}$ and $\mathrm{e}$.

As regards Lolium perenne (TABLE $5 \mathrm{C}$ ), it should be remembered that all mixtures contained this grass.

On plots where the mixture contained Festuca rubra less Lolium perenne was found than on the plots sown with a mixture not containing Festuca rubra.

The presence of Agrostis stolonifera in the mixture appears to have little if any effect on the coverage of Lolium perenne. 
TABLE 4. Relation between habitat factors and the area covered by some species on the experimental field near Rotterdamse Hoek according to the Wilcoxon- $T$ test

\begin{tabular}{|c|c|c|c|c|c|c|c|c|c|c|}
\hline Soil type & Gradient & As & Fr & $\mathrm{Fp}$ & $\mathbf{L p}$ & $\mathrm{Pp}$ & $\mathrm{Pt}$ & Trif & $\mathrm{Br}$ & $\begin{array}{l}\text { Spec } \\
\text { div. }\end{array}$ \\
\hline Silty clay loam & $\begin{array}{l}1: \infty \\
1: 2.5\end{array}$ & : & $\dot{\bullet}$ & & \pm & : & & \pm & • & $\dot{.}$ \\
\hline Sand & $\begin{array}{l}1: 30 \\
1: 5\end{array}$ & $\overline{+}$ & $\overline{+}$ & \pm & \pm & $\dot{.}$ & \pm & \pm & & $\dot{.}$ \\
\hline $\begin{array}{l}\text { Sand } \\
\text { Silty clay loam }\end{array}$ & $\begin{array}{l}1: 5 \\
1: 2.5\end{array}$ & + & \pm & & \pm & & & \pm & $\bar{t}$ & \pm \\
\hline $\begin{array}{l}\text { Sand } \\
\text { Silty clay loam }\end{array}$ & $\begin{array}{l}1: 30 \\
1: \infty\end{array}$ & $\bar{t}$ & $\bar{t}$ & \pm & $\stackrel{+}{-}$ & \pm & \pm & \pm & $\overline{+}$ & \pm \\
\hline
\end{tabular}

TABLE 5. Average sequence of the seed mixtures arranged according to the percentage coverage of Agrostis stolonifera (A), Festuca rubra (B) and Lolium perenne (C). The area covered increases from left to right. + and denote whether or not the species was sown; $\infty$ indicates that the difference is insignificant

\begin{tabular}{|c|c|c|c|c|c|c|c|c|c|c|c|c|c|}
\hline \multirow[b]{2}{*}{ A } & \multirow[t]{2}{*}{ Species } & \multicolumn{12}{|c|}{ Mixture } \\
\hline & & b & & d & & g & $\infty$ & $\mathrm{a}$ & $\infty$ & f & & c & e \\
\hline & As & - & & - & & + & & - & & + & & + & + \\
\hline & $\mathbf{F r}$ & + & & + & & + & & - & & + & & - & - \\
\hline \multirow[t]{3}{*}{ B } & & $\mathbf{a}$ & & c & & $\mathbf{e}$ & & $\mathbf{g}$ & & $\mathbf{f}$ & & d & $\mathbf{b}$ \\
\hline & $\mathrm{Fr}$ & - & & - & & - & & + & & + & & + & + \\
\hline & As & - & & + & & + & & + & & + & & - & - \\
\hline \multirow[t]{4}{*}{$\mathbf{C}$} & & $\mathrm{g}$ & $\infty$ & d & $\infty$ & f & $\infty$ & b & & c & $\infty$ & e & $\mathbf{a}$ \\
\hline & Lp & + & & + & & + & & + & & + & & + & + \\
\hline & As & + & & - & & + & & - & & + & & + & - \\
\hline & Fr & + & & + & & + & & + & & - & & - & - \\
\hline
\end{tabular}

Kendall, M. G. Kruinne, A. A., D. M. DE VRIES and $\mathrm{H}$. Moor

TATE, M. W., and R. C. Clelland

VRIES, D. M. DE

\section{REFERENCES}

1948 Rank correlation methods. London.

1963 Data concerning important herbage plants. Meded. I.B.S. Wageningen. No. 225,45 pp.

1959 Non parametric and shortcut statistics. Hlinois, U.S.A.

1959 Botanische samenstelling en dichtheid van de grasmat op de dijken in Nederland. In: Rapport Grasmat op dijken. Kon. Inst. Ing. en Kon. Gen. LandbWet., Leiden, 26-58. 